\title{
Pet zastava, četiri države, jedno državljanstvo - čije su medalje? ${ }^{1}$
}

\section{Sunčica Bartoluci}

Sveučilište u Zagrebu, Kineziološki fakultet, Hrvatska e-mail: suncica.bartoluci@kif.hr

\section{Lorena Draženović}

Sveučilište u Zagrebu, Kineziološki fakultet, Hrvatska e-mail: lorena.drazenovic@kif.hr

\begin{abstract}
SAŽETAK Streljačica Jasna Šekarić sportašica je koja je u iznimno dugoj sportskoj karijeri nastupala pod pet različitih zastava, za četiri različite države, ne mijenjajući pritom državljanstvo. Rad analizira utjecaj društveno-političkih okolnosti na percepciju njenog sportskog uspjeha te oblikovanje nacionalnog identiteta od kraja osamdesetih godina prošloga stoljeća do današnjih dana. Kao teorijski okvir korištena je dihotomija građanskog i etničkog nacionalizma Anthonyja D. Smitha (1991.). Zanimalo nas je kako se mijenja određeni tip nacionalizma u četirima proučavanim razdobljima (četiri države za koje je Šekarić nastupala). Pretpostavili smo da društveno-političke okolnosti mogu značajno utjecati na percepciju određenog sportskog uspjeha. S obzirom na velika previranja i promjene u društvu, tijekom proučavanih razdoblja izmjenjivali su se etnički i građanski nacionalizam, ovisno o zbivanjima u širem društvu. U svrhu prikupljanja podataka za dokazivanje postavljenih hipoteza provedeno je kvalitativno istraživanje metodom studije slučaja. Za analizu slučaja korištena su tri polustrukturirana intervjua sa sportskim akterima te analiza diskursa (novinskih članaka i članaka iz časopisa, članaka s interneta te raznih dokumenata). Analiza slučaja potvrdila je postavljenu hipotezu i pokazala je kako su promatrane društveno-političke okolnosti utjecale na percepciju sportskog uspjeha Jasne Šekarić. Isto tako pokazalo se kako u četirima proučavanim razdobljima nije moguće prepoznati jednoznačna obilježja etničkog odnosno građanskog tipa nacionalizma.
\end{abstract}

Ključne riječi: nacionalni identitet, sport, etnički nacionalizam, građanski nacionalizam, streljaštvo.

1 Tekst je dijelom nastao iz rada Lorene Draženović: Pet zastava, pet medalja, osam Olimpijskih igara: Jasna Šekaric - studija slučaja, izrađenog pod mentorstvom Sunčice Bartoluci, koji je akademske godine 2014./15. nagrađen Rektorovom nagradom za znanstveni rad. 


\section{Uvod}

Pitanja povezanosti nacionalizma i sporta neiscrpna su tema istraživanja različitih društveno-humanističkih znanosti, posebice posljednjih dvadesetak godina. S padom komunizma i promjenom geopolitičke karte svijeta te slijedom posljedica koje su te promjene imale na društvo u cjelini sport više nego ikada prije postaje sredstvo putem kojeg se novonastale nacije-države pokušavaju afirmirati na međunarodnoj sceni. Sociolozi sporta tvrde kako sport ne može biti puno drugačiji od društva kojeg je dio, te je zato važno usredotočiti se na istraživanje njegovog „dubljeg značenja“ unutar šireg društvenog konteksta (Perasović i Bartoluci, 2007.). S obzirom na navedeno cilj je rada bio istražiti kako društveno-političke okolnosti utječu na percepciju određenog sportskog uspjeha te kako se mijenja tip nacionalizma s obzirom na navedene okolnosti. Kroz analizu slučaja sportskog uspjeha najtrofejnije streljačice svih vremena Jasne Šekarić nastojalo se pokazati u kojoj se mjeri isprepliću sport i nacionalni identitet te kakva je njihova povezanost s društveno-političkim okolnostima. Slučaj Jasne Šekarić indikativan je i zbog toga što je tijekom sportske karijere nastupala pod pet različitih zastava, za četiri države, ne mijenjajući pritom državljanstvo.

U suvremenom društvu sport i nacionalni identitet višestruko su povezani. Sport, posebno vrhunski, u velikoj mjeri postaje globalni, gotovo univerzalni društveni fenomen, te ima implikacije na čitav niz područja - politiku, ekonomiju, turizam itd. Veliki sportski događaji zaokupljaju pažnju milijuna ljudi širom svijeta, čime sport dobiva potencijal pokretača društvenih promjena, bilo pozitivnih bilo negativnih. Opće je poznato da sportski uspjeh te prisutnost nacionalnih simbola kao što su zastava i himna mogu probuditi nacionalne osjećaje te osjećaj pripadnosti određenoj grupi čak i među populacijom koja nije u velikoj mjeri zainteresirana za sport (Bartoluci, 2013.). Brojna istraživanja pokazuju da je sport više od igre, susreta ili utakmice. Bavljenje sportom kao i njegovo praćenje može u većoj mjeri utjecati na stvaranje identiteta osobe. Zbog masovnosti i velike popularnosti sport se smatra možda najvažnijim kulturnim i političkim fenomenom naše epohe (Harrison, 1988.). Današnja istraživanja u sociologiji sporta pokazuju kako je sport jedna od temeljnih društvenih institucija, neodvojiva od strukture društva i institucija obitelji, gospodarstva, medija, politike, obrazovanja, religije i sl. (Perasović i Bartoluci, 2007.). Osim toga poznato je da većina nacija slavi uspjehe svojih sportaša, pa se može reći da sport igra važnu ulogu u stvaranju i reproduciranju nacionalnih identiteta koje uključuje. Sport se često koristi kao „društveni sigurnosni ventil za postojeće društvene tenzije i frustracije“, ali i kao „društveni kompenzacijski mehanizam za postojeće deficite u drugim, životno mnogo značajnijim područjima“, pružajući tako sudionicima sportskih događaja stanovitu „nadoknadu deficita demokratske participacije“ u važnim društvenim pitanjima (Vrcan, 1990::123).

Sport je kroz povijest često bio „produžena ruka politike“, pogotovo u trenucima kada ga se koristilo za konstruiranje nacionalnog identiteta pojedinca ili društva u cjelini. Brojni su primjeri država koje političku afirmaciju na međunarodnoj sceni pokušavaju uspostaviti i učvrstiti upravo putem sporta i sportskih uspjeha. Takav je i primjer Hrvatske, koja je nakon osamostaljenja sportske uspjehe koristila kako bi u svijetu postala što „vidljivija“ (Bartoluci, 2013.). 
Sport ovisi o dominantnoj kulturi i vrijednostima određenog društva. Kao dio kulture društva ljudska je tvorevina koja se mijenja paralelno s društvom u cjelini. S obzirom na tu činjenicu ne čudi podatak da streljaštvo slovi kao jedan od najstarijih sportova u Hrvatskoj, ali i svijetu. U bivšoj Jugoslaviji svi učenici osnovnih škola pohađali su predmet Općenarodna obrana i društvena samozaštita, čiji je sastavni dio bilo, između ostalog, i gađanje iz puške. Streljaštvo je natjecateljski sport koji razvija umijeće pogađanja pokretnih i nepokretnih meta korištenjem različitih vrsta oružja. Standardni je sport u programu modernih Olimpijskih igara, no unatoč tome smatra ga se tzv. malim sportom. Strijelci su vrlo rijetko predmet transfera (za razliku od, primjerice, nogometaša), na natjecanjima nema službenih uniformi (osim kada se radi o nastupu za reprezentaciju), natjecanja medijski nisu popraćena (kao što su npr. rukometne utakmice), sportaši se rijetko mogu nazvati profesionalcima budući da su plaće izuzetno rijetka pojava i sl.

\section{Nacionalni identitet i nacionalizam}

Kako ističu brojni autori, ne postoji jednoznačna i općeprihvaćena definicija nacije - pri njenom definiranju koriste se različiti elementi kao što su osjećaj zajedničke prošlosti i podrijetla ili pak zajednički jezik, religijska pripadnost, kulturno naslijeđe (Ravlić i Sekulić, 2008.). Nacije nastaju kao rezultat kontinuiranih povijesnih procesa, različitih u vremenu i prostoru. Dva idealnotipska određenja nacije bila bi: nacija kao kulturna zajednica (naglasak je na etničkoj povezanosti) te nacija kao politička zajednica (gdje dominira građansko-teritorijalni princip). Slično tome, Anthony D. Smith (1991.) razlikuje dva tipa nacionalnog identiteta: etnički i građansko-teritorijalni. Etnički ili „istočni“ identitet proizlazi iz ideje nacije kao etničke i kulturne zajednice. Bilo da napuštate svoju zajednicu ili da emigrirate u drugu, kaže Smith (1991.:11), neizbježno, organski ostajete pripadnik zajednice svog rođenja i zauvijek nosite njen žig. Kod tog oblika identiteta u prvi plan dolaze povijesno porijeklo, zajednički mitovi i povijesna sjećanja. Učvršćuje se obrazovanjem i nacionalnim institucijama, a putem obreda i ceremonija nastoji se sugerirati kontinuitet etničke tradicije i homogenost nacije. U tu svrhu ističu se određene „povijesne“ ličnosti, znameniti događaji i mitovi kao podsjetnik na zajedničko porijeklo i kulturu. Građansko-teritorijalni ili „zapadni“ identitet temelji se na ideji nacije kao zajednice građana, a vezan je za modernu državu. Nacije moraju posjedovati utvrđeni teritorij kao mjesto života. Među pripadnicima zajednice treba postojati osjećaj pravne jednakosti. Svi se građani moraju moći aktivno participirati u takvoj teritorijalno uređenoj zajednici. Pojedinac treba pripadati nekoj naciji, ali može sam izabrati kojoj.

Smith tvrdi kako svaki nacionalizam sadrži i građanske i etničke elemente. Usvajajući znanja o zajedničkom porijeklu, kulturi i simbolima, slavnim ličnostima i herojskoj povijesti, jačaju se spone među pripadnicima nacije, što pridonosi afirmaciji nacionalnog identiteta. Identifikacija s nacijom najsigurniji je način nadilaženja konačnosti i osiguravanja neke vrste besmrtnosti (1991.:160-161).

O nacionalizmu se govori kao o negativnom, ali i kao o pozitivnom fenomenu, ovisno o kontekstu u kojem ga se spominje. Većinom ga se opisuje kao ideologiju 
kojom se stvaraju podjele na „nas“ i „njih“. Kada govorimo o nacionalizmu u negativnom kontekstu, bitno je osvrnuti se i na ksenofobiju, kao negativnu posljedicu nacionalizma. Nacionalizam je također moguće odrediti i kao pokret koji pokazuje želju neke nacije za osamostaljenjem, ali i ideologiju za postizanje autonomije, jedinstva i identiteta nacije. U sociološkoj literaturi navode se različite tipologije nacionalizma: građanski/etnički, politički/kulturni, miroljubivi/agresivni, liberalni/ integralni. Postoje i složenije klasifikacije, koje razlikuju liberalni, imperijalistički, antikolonijalni, konzervativni i integralni nacionalizam.

Za potrebe ovog rada posebice su zanimljivi etnički i građanski oblik nacionalizma. Etnički nacionalizam karakterizira poimanje pripadanja naciji na temeljima zajednice porijekla, loze ili krvi (McCrone, 1998.). Etnički je identitet određen rođenjem i nije stvar izbora pojedinca. Etnički nacionalizam zahtijeva od svojih članova da budu odani naciji te da pokušaju „očistiti“ teritorij od stranaca, što obično rezultira nasiljem, etničkim čišćenjem ili genocidom. Središnja ideja građanskog nacionalizma mogućnost je izbora nacionalnog identiteta. Pripadnost naciji nije određena rođenjem pojedinca. Građanske nacije u pravilu su otvorene svima koji pristaju poštivati njezine zakone. Građanski nacionalizam usko je povezan s državljanstvom i teritorijem. Kako navodi Lakoff (2000.:58), politički ili građanski oblik nacionalizma razlikuje se od etničkog i spojiv je s demokracijom jer u načelu ne isključuje nikoga tko ima pravo na državljanstvo rođenjem ili naturalizacijom - njemu je cilj ujediniti pripadnike određene zajednice bez obzira na njihove druge pripadnosti, isticanjem zajedničkih simbola i institucija. Također, „poput demokracije, politički ili građanski nacionalizam podrazumijeva odanost kolektivnom 'samoodređenju' cijelog pučanstva, bez obzira na etničku, vjersku ili rasnu pripadnost ili bilo koju drugu kulturnu razliku, jezik ili narječje. I politički nacionalizam i demokracija ukorijenjeni su u postavci da oni koji nastanjuju određenu teritorijalnu državu ili teže zajedničkoj državi dijele stanoviti osjećaj političkog identiteta. Nacionalizam u ovom političkom ili građanskom značenju toga pojma podudaran je s demokracijom“ (Lakoff, 2000.:58).

\subsection{Nacionalni identitet $i$ sport}

Odnos nacionalnog identiteta i sporta kompleksan je i višeznačan. U hrvatskom društvu upravo su sport i sportski uspjesi odigrali važnu ulogu u konstruiranju nacionalnog identiteta (Bartoluci, 2013.). S obzirom na to da dosadašnja istraživanja pokazuju kako društveno okruženje značajno utječe na odnos sporta i nacionalnog identiteta, odlučili smo to provjeriti ovim istraživanjem te vidjeti na koji način društveno okruženje utječe na percepciju sportskog uspjeha. Pretpostavili smo da zbog društveno-političke situacije na prostorima današnjih nacija-država Hrvatske i Srbije u prvom (1980. - 1991.) i drugom razdoblju (1992. - 2003.) dominira etnički oblik nacionalizma, a u trećem (2003. - 2006.) i četvrtom razdoblju (2006. -) zbog završetka rata i normalizacije društveno-političke situacije počinje prevladavati građanski oblik nacionalizma. Također smo pretpostavili da društveno-političke okolnosti utječu na percepciju sportskog uspjeha. 
U karijeri koja traje od 1980. godine, a koja je obilježena osvajanjem velikog broja odličja, Jasna Šekarić nastupala je za četiri različite države. Prvo razdoblje, kada nastupa za Socijalističku Federativnu Republiku Jugoslaviju (SFRJ), traje od početka aktivne karijere do 1991. godine, kada dolazi do formiranja novih nacionalnih država. Najprije iz zajedničke države istupaju Hrvatska i Slovenija, a nešto kasnije Makedonija te Bosna i Hercegovina. Ubrzo nakon proglašenja neovisnosti počeo je desetodnevni rat u Sloveniji. Nedugo zatim započinje i rat u Hrvatskoj, koji je trajao do 1995. godine. U prvom razdoblju Jasna Šekarić nastupat će na Olimpijskim igrama u Seoulu, gdje će osvojiti dvije olimpijske medalje, zlatnu i brončanu.

1992. godine Hrvatska je nastupala na svojim prvim zimskim i ljetnim Olimpijskim igrama te su njeni sportaši osvojili prve medalje pod hrvatskom zastavom. Ti rezultati bili su izuzetno važni za oblikovanje i utvrđivanje hrvatskog nacionalnog identiteta, te su imali posebno značenje za hrvatsko društvo. U 1990-ima hrvatski nacionalizam bio je povezan s izražavanjem želje za političkom samostalnošću i raskidom odnosa s Jugoslavijom. Ratna razaranja u Hrvatskoj istaknula su značaj nacionalnog identiteta te želju za njegovim očuvanjem. Ljudi su stradavali zbog etničkog podrijetla ili vjerske pripadnosti, kriterij etniciteta i konfesionalnosti postao je kriterijem života ili smrti. S obzirom na brutalnu agresiju protiv Hrvatske i s obzirom na nacionalistički diskurs koji je prevladavao, za dio tada vladajuće političke elite u Hrvatskoj u prvi plan dolaze pitanja porijekla, srodstva, „čistoće“ krvi, loze i sl., a neki političari (kao npr. Šime Đodan) idu tako daleko da tvrde da se Srbi mogu prepoznati po fizičkim karakteristikama. Dio traumatične povijesti iz razdoblja Drugog svjetskog rata pojedinci u hrvatskom društvu nastoje uljepšati i mitologizirati. Počinje dominirati etnički oblik nacionalizma. Taj će oblik ostati dominantan do kraja devedesetih godina, a nakon političkih promjena u dvijetisućitima započinje razdoblje transformacije etničkog u građanski nacionalizam.

Kad je riječ o Srbiji, tamo je krajem osamdesetih započeo rasti nacionalistički pokret, koji je, uz Slobodana Miloševića kao vođu, postao glavna društvena i politička snaga. Od prvih „mitinga istine“ (o položaju srpskog naroda na Kosovu), preko „antibirokratske revolucije“, do nacionalizma kao ideologije jednog osvajačkog državnog i vojnog projekta, u Srbiji se sportski uspjeh smatrao ključnim za samopouzdanje i osnaživanje nacionalnog identiteta. U istom razdoblju u Bosni i Hercegovini rat je započeo 1992. a okončan je 1995. godine.

U drugom razdoblju Srbija i Crna Gora formiraju novu saveznu državu - Saveznu Republiku Jugoslaviju, koja će pod tim imenom postojati od 1992. do 2003. godine. Jasna Šekarić u tom će razdoblju nastupati na Olimpijskim igrama tri puta, 1992. u Barceloni bez nacionalnih obilježja, 1996. u Atlanti te 2000. godine u Sydneyju. U trećem razdoblju ponovo će doći do promjene imena države. Jasna Šekarić od 2003. do 2006. nastupa za Državnu zajednicu Srbije i Crne Gore, predstavljajući je na Olimpijskim igrama u Ateni 2004. godine, gdje će osvojiti srebrnu medalju. Nakon odcjepljenja Crne Gore, od 2006. godine nadalje, govorimo o četvrtom razdoblju, kada Jasna Šekarić nastupa za Republiku Srbiju. U tom razdoblju natjecala se na Olimpijskim igrama u Pekingu 2008. te u Londonu 2012. godine, ali nije uspjela osvojiti medalju. Izborila je i nastup na posljednjim Olimpijskim igrama 2016. godi- 
ne u Riju de Janeiru, no unatoč ostvarenoj olimpijskoj normi, odlukom nacionalnog streljačkog saveza, umjesto nje nastupio je drugi strijelac.

\section{Operacionalizacija pojmova za razlikovanje etničkog i građanskog nacionalizma}

Da bismo što bolje proveli analizu te dokazali već navedene hipoteze, sistematizirat ćemo indikatore koji su bitni za razlikovanje etničkog od građanskog nacionalnog identiteta. Kao model poslužit će nam sistematizacija indikatora koje je u svom istraživanju primijenila Bartoluci (2013.). Fokusirat ćemo se na analizu triju diskursa: političkog, medijskog i diskursa samih sportskih aktera.

\subsection{Indikatori političke involviranosti}

U ovom slučaju političku involviranost čine:

- $\quad$ prisutnost političara na dočeku nakon sportskog uspjeha

- izjave političara koji uspjeh stavljaju u kontekst nacionalnog ili sportskog događaja

- odlikovanje sportaša od političkih elita.

Prisutnost političara na dočeku smatramo indikatorom etničkog nacionalizma ako je ta prisutnost redovita, podrazumijevajuća, uključuje ulaženje u svlačionicu i druge oblike stalne vezanosti. Građanski nacionalizam ne podrazumijeva takvu naglašenu prisutnost političara na sportskim svečanostima, ali, naravno, ni ne isključuje prisutnost političara na sportskim priredbama.

Također, izjave političara koje sportski uspjeh stavljaju prvenstveno u nacionalni kontekst indikator su etničkog nacionalizma. Izjave koje se stavljaju u sportski kontekst i koje naglašavaju određeni rezultat kao uspjeh sportaša pripadaju građanskom obliku nacionalizma. Čest je slučaj da je u izjavama vidljiva kombinacija etničkog i građanskog nacionalizma.

Što se odlikovanja sportaša tiče, ukoliko se naglašava nacionalni uspjeh, to je indikator etničkog nacionalizma, no ukoliko se naglašava isključivo sportski uspjeh, tada je to indikator građanskog nacionalizma.

\subsection{Indikatori medijske involviranosti}

Indikatore medijske involviranosti u našem slučaju čine:

- $\quad$ stavljanje sportskog događaja u kontekst nacionalnog uspjeha

- $\quad$ stavljanje sportskog uspjeha u kontekst uspjeha pojedinca.

Kada se određeni sportski uspjeh interpretira kao uspjeh nacije, odnosno kada ga se stavlja u kontekst nacionalnog uspjeha, tada je to indikator etničkog nacionalizma. 
Građanski nacionalizam karakterizira naglašavanje uspjeha kao zasluge sportaša, kao posljedice njihova truda, rada i odricanja. Naravno da se i u tom slučaju javlja mogućnost postojanja kombinacije građanskog i etničkog oblika nacionalizma. Ono što je također nagovještaj etničkog nacionalizma jest i neizvještavanje o određenim uspjesima sportaša.

\subsection{Indikatori diskursa sportskih aktera}

Ukoliko akteri sportski uspjeh stavljaju u kontekst nacionalnog uspjeha, odnosno ukoliko se govori o sportskom uspjehu kao presudnom za državu, to je indikator postojanja etničkog oblika nacionalizma. Kada se fokus stavlja isključivo na rezultat u sportskom kontekstu, tada govorimo o građanskom nacionalizmu.

Također, i u ovom slučaju, moguća je kombinacija građanskog i etničkog oblika nacionalizma. Ukoliko se sportašima daje poseban status, npr. „nacionalnog heroja“, tada možemo govoriti o etničkom obliku nacionalizma.

\section{Metodologija}

U svrhu prikupljanja podataka koji su potrebni za provjeru hipoteza tijekom 2014. i 2015. godine provedeno je kvalitativno istraživanje metodom studije slučaja. Ta se metoda razlikuje od ostalih po tome što podrazumijeva intenzivnu analizu te opis pojedinačne jedinke ili sustava povezanog prostorom i vremenom (Hancock i Algozzine, 2006.). Studija slučaja obuhvaća intenzivno istraživanje određenog slučaja, a bazira se na argumentu da razumijevanje ljudske aktivnosti podrazumijeva kako njezin razvoj tijekom vremena tako i okolinu i kontekst u kojima se određena aktivnost pojavljuje (Gratton i Jones, 2010.). Za analizu konkretnog slučaja korištene su dvije istraživačke metode: tri polustrukturirana intervjua sa sportskim akterima (Jasnom Šekarić, Zvonimirom Kovačevićem i Mirelom Skoko-Ćelić) te analiza diskursa medijskih objava i dokumenata (časopisa, novina, internetskih izvora), koja je provedena na trima razinama (političkog diskursa, medijskog diskursa te diskursa sportskih aktera).

U ovom istraživanju provedeni su polustrukturirani intervjui kako bi se s jedne strane zadržala tematska struktura, a s druge strane dopustio spontani i dublji tijek razgovora. Prvi intervju, s Jasnom Šekarić, proveden je u prosincu 2014. godine u Zagrebu. Drugi, s njezinim bivšim trenerom Zvonimirom Kovačevićem, kao i treći intervju s Mirelom Skoko-Ćelić, nekadašnjom reprezentativkom i klupskom kolegicom provedeni su tijekom siječnja 2015. godine u Osijeku. Svaki intervju trajao je između 30 i 60 minuta. Intervjui su snimani diktafonom te su za potrebe daljnje analize napravljeni transkripti. Svi su ispitanici dali autoricama pravo navođenja i citiranja pod imenom i prezimenom. Istraživanje je provedeno uz odobrenje Etičkog povjerenstva Kineziološkog fakulteta Sveučilišta u Zagrebu. 
Gall i sur. (1996., cit. prema Gratton i Jones, 2010.:107) navode četiri karakteristike studije slučaja: 1 . pojave se proučavaju kroz fokusiranje na pojedinačne slučajeve (pa smo se tako u radu fokusirali isključivo na slučaj Jasne Šekarić); 2. svaki se slučaj istražuje u dubinu (da bismo uspjeli dokazati postavljene hipoteze, potrebno je istražiti slučaj u dubinu, fokusirati se ne samo na sadašnjost nego i na prošlost); 3. pojave se proučavaju u svom prirodnom kontekstu (proučavali smo uspjehe Jasne Šekarić tijekom velikih natjecanja kao i reakcije javnosti na njene uspjehe); 4. studija slučaja bazira se na perspektivi proučavanih radije nego na perspektivi istraživača (tijekom istraživanja stavljao se naglasak na perspektivu aktera, prvenstveno same Jasne Šekarić, pa nam je bilo iznimno važno vidjeti na koji način ona razmišlja i percipira svoje uspjehe te kako te uspjehe percipira javnost).

Studija ovog slučaja služi nam kao pokazatelj društveno-političkih promjena u širem društvu. Ono što je konstantno jesu sportski uspjesi Jasne Šekarić i njezina vlastita percepcija uspjeha. Ono što je različito jesu zastave pod kojima nastupa, države-nacije za koje osvaja medalje te na kraju i percepcija tih uspjeha u javnosti. Analizom konkretnog slučaja možemo vidjeti da je sport poput „lakmus papira“. Kako lakmus papir mijenja svoju boju ovisno o tekućini u koju je uronjen, tako se i uspjesi Jasne Šekarić gledaju na drugačije načine ovisno o tome kada je i u kakvim društvenopolitičkim okolnostima ostvarila određeni rezultat.

Analiza diskursa bavi se proučavanjem jezika iznad nivoa rečenice, ne zanemarujući niže nivoe te obuhvaća mehanizme pomoću kojih može proučavati razne vrste govora ili pisanog teksta (Lakić, 2009.:92). Treba razlikovati analizu diskursa kao cilj sam po sebi i analizu diskursa u druge svrhe. Lingvisti analiziraju diskurs jer ih zanima diskurs sam po sebi, a druge društvene discipline, kao što je, primjerice, sociologija, analiziraju diskurs kako bi saznale nešto o ostalim aspektima ljudskog života ili društva. Tako je u ovom konkretnom radu korištena analiza diskursa da bismo saznali kako se mijenja percepcija uspjeha sukladno društveno-političkim promjenama. Provedena je analiza diskursa na trima razinama: medijski diskurs, politički diskurs te diskurs sportskih aktera. Unutar medijskog i političkog diskursa analizirana su hrvatska izdanja dnevnih novina od pet dana prije, tijekom i pet dana nakon Olimpijskih igara - Sportske novosti, Večernji list, Glas Slavonije i Vjesnik, iz 1988., 1992. te 1996. godine te časopisi Strelac i Streljaštvo iz 1988. i 1992. godine. Analizirani su mrežni izvori Jutarnjeg lista i Večernjeg lista iz 2000., 2004., 2008., 2012. i 2016. godine. Također, analizirani su novinski članci srpskih mrežnih izdanja Politike, Sportskog žurnala i Večernjih novosti te portala B92.net, Blic.rs, Dnevnik.net, Ebritic.com, Kurir.rs, Mozzartsport.com, Nezavisne.com, RTS.rs, Sportal.rs, Sportskacentrala.com, i Sportske.net od pet dana prije, tijekom i pet dana nakon održavanja Olimpijskih igara 2000., 2004., 2008., 2012. i 2016. godine. Unutar diskursa aktera analizirana su tri intervjua (s Jasnom Šekarić, Zvonimirom Kovačevićem te Mirelom Skoko-Ćelić). 


\section{Rezultati i rasprava}

Jasna Šekarić rođena je 1965. godine u Beogradu. Budući da joj je otac bio djelatno vojno lice, obitelj se često selila. S nepunih pet godina doselila je u Osijek, gdje je završila osnovnu i srednju školu. Streljaštvom se počela baviti krajem osmog razreda, i to sasvim slučajno. Naime tada je tijekom osnovnoškolskog obrazovanja bilo obavezno pohađati predmet Općenarodna obrana i društvena samozaštita. Gađati puškom započela je kao dio školske ekipe nastupajući za školsku ligu. Tri godine nakon toga Osijek je dobio domaćinstvo Europskog prvenstva u streljaštvu. Budući da nisu imali predstavnike, trener je odlučio da će Jasna Šekarić prijeći na disciplinu zračni pištolj. 1985. godine, nakon samo dvije godine treniranja osvaja Europsko prvenstvo u Osijeku. Godinu dana nakon toga postaje seniorska prvakinja države (Socijalističke Federativne Republike Jugoslavije), a 1987. i svjetska prvakinja. 1988. godine nastupa u Seoulu na svojim prvim Olimpijskim igrama. U Osijek se vraća s dvjema osvojenim medaljama - zlatom u zračnom te broncom u malokalibarskom pištolju. Od tada do danas nastupala je na sedam Olimpijskih igara te je osvojila još tri srebrne medalje (1992., 2000., 2004.). Godine 1990. beogradska Crvena zvezda nudi joj nekadašnjih 40.000 njemačkih maraka za prelazak u njihov klub na dvije godine, što Jasna Šekarić prihvaća. Zbog predstojećeg rata, koji je u velikoj mjeri onemogućio normalan život na prostoru Istočne Hrvatske, ostaje živjeti i raditi u Beogradu.

Od početka profesionalne karijere do danas Jasna Šekarić osvojila je sva najvrjednija odličja (na svjetskim i europskim prvenstvima te Olimpijskim igrama), postavila je dva rekorda te jedan izjednačila (hrvatski, srpski te svjetski), dva puta je nagrađena zlatnom značkom sporta, tri je puta bila proglašavana najboljim strijelcem godine te je odlukom Međunarodne streljačke federacije proglašena najboljim strijelcem 20. stoljeća. Također je uvrštena među deset najboljih sportaša svijeta po broju odlazaka na Olimpijske igre - posljednje u Riju de Janeiru bile bi njezine osme igre, no unatoč ostvarenoj kvoti odlukom nacionalnog streljačkog saveza nije nastupila.

Slučaj Jasne Šekarić sociološki je interesantan iz dvaju razloga. Prvi je taj što je jedina sportašica koja je na Olimpijskim igrama nastupala pod pet različitih zastava: Socijalističke Federativne Republike Jugoslavije (SFRJ), pod olimpijskom zastavom, zastavom Savezne Republike Jugoslavije, Državne zajednice Srbije i Crne Gore te Republike Srbije. O važnosti nastupanja pod nacionalnom zastavom kaže:

Pa ne, bitno je pod kojom zastavom [nastupaš]. Bitno je jer država i jeste identitet neke osobe. Znači ja ne mogu da budem niotkud, prosto da znači čoveku da zna odakle je, gde su mi korjeni i odakle su moji preci na kraju krajeva, da sam ja deo tog nekog društva, sigurno da znači. Meni lično znači. (Jasna Šekarić, intervju, Zagreb, 6. 12. 2014.)

Drugi je razlog sociološke razrade slučaja Jasne Šekarić i taj da se tijekom života natjecala za četiri različite države, a da pritom nije mijenjala državljanstvo. O učestalim promjenama država za koje je nastupala kaže: 
Meni je prvo bio nepojmljivo to da smo mi bili Jugoslavija $i$ kad je uopšte krenilo ono da dolazi do raspada, to je meni jako teško palo. Jako mi je teško palo, verovatno zato što sam tako i odgajana. Moj je otac bio vojno lice $i$ to se znalo, država je uvek ono nešto što se voli i što je bitno i ja sam ju tako doživljavala, ja sam tako odgajana. I onda nešto se desi, meni je to bilo nepojmljivo. Ja lično nisam mogla da verujem da će to otići u smeru u kojem je otišlo, na žalost je otišlo. Ali eto, volela sam da nastupam pod zastavom Jugoslavije, nisam volela da nastupam pod belom zastavom IOP-a. Volela sam posle i tu zastavu Srbije $i$ Crne Gore, a sigurno da volim i što eto sada nastupam za Srbiju. Mislim da je svakom sportisti bitno da ima nekog iza sebe. (Jasna Šekarić, intervju, Zagreb, 6. 12. 2014.)

U prvom razdoblju nastupa za Socijalističku Federativnu Republiku Jugoslaviju (SFRJ), od početaka svoje aktivne karijere osamdesetih godina do raspada države 1991. godine. Analizirane medijske objave pokazuju prevladavanje sportskog diskursa tipičnog za građanski nacionalizam. Članci se podjednako objavljuju u svim novinama te su pozitivno intonirani. U prvom je planu sportski uspjeh Jasne Šekarić. Annemarie Jutel (2002.) navodi da je pripadnost određenoj naciji jedan od preduvjeta za nastup na mnogim sportskim natjecanjima. Nacionalne sportske organizacije selektiraju sportaše za nastupe na velikim natjecanjima. Budući da je Savezna Republika Jugoslavija (tj. Srbija i Crna Gora) 1992. godine, u drugom razdoblju, bila pod međunarodnim sankcijama Ujedinjenih naroda, u prvi plan došlo je pitanje hoće li njihovim sportašima biti dozvoljeno nastupati na Olimpijskim igrama u Barceloni. Konačna odluka bila je da se nastup dozvoljava samo sportašima u pojedinačnoj konkurenciji, kao nezavisnim olimpijskim natjecateljima - Independent Olympic Participants (IOP), u bijelim dresovima, pod olimpijskom zastavom te bez istaknutog nacionalnog znakovlja. Te su Igre bile izuzetno kompleksne za srpske i crnogorske sportaše, što najbolje opisuje izjava Jasne Šekarić:

Pa to je za mene lično baš bilo teško zato što tada su donešene sankcije, tada ja ne znam ni kako smo se zvali, ja sam promenila četiri države. [...] mislim to je prosto neverovatno $i$ onda prosto moram da se setim u kojem periodu je bila koja država. Da, onda su nastupile sankcije, za tada ja mislim, Srbiju i Crnu Goru i nismo znali da li uopšte idemo ili ne pošto su kao sankcije. Prvo je bilo neće sport biti uključen u to pa je onda i sport bio uključen u to $i$ onda smo mi dva dana pred odlazak saznali da idu samo pojedinačni sportovi upravo zbog toga da ne bi mogli da se identifikujemo kao država. I sad mi smo išli pod specijalnim uslovima tamo, da ne sme da imamo nikakva obilježja kod sebe, znači to je bilo Independent Olympic Participants, znači nezavisni olimpijski takmičari recimo tako. IOP - to nam je bila skraćenica. I nismo smeli naravno kao nikakav identitet, ništa (vamo-tamo). Mecutim atmosfera u ekipi je bila onako (ajd da kažem) teško je dosta bilo, baš zato jer nije se znalo jel idemo. I sad neki naši (ajd da kažem) sportski prijatelji su bili uskraćeni za to, ostali su kući. Nismo sad mi mogli da idemo tamo 'jupi, jubu, mi smo ipak otišli’. Prosto pod tim utiskom onako prilično je mučno bilo. (Jasna Šekarić, intervju, Zagreb, 6. 12. 2014.) 
Navedena izjava indikator je građanskog nacionalizma jer u prvi plan stavlja sport i sportski uspjeh. Kao što je vidljivo iz priloženog, Jasni Šekarić nije bitno pod kojom će zastavom nastupati i nema problem s nastupima pod različitim zastavama. Ono što je važno jest potpora države te sportski uspjeh. Ipak moramo primijetiti kako je unutar prevladavajućeg diskursa građanskog nacionalizma prisutan i onaj etnički jer joj je također važno „da se zna odakle su korijeni“ i ,gdje su preci“, da sportaš nije došao niotkud, da od nekud potječe i nekome pripada. Iako se radi o njenom osobnom, sportskom uspjehu, važno joj je da iza nje stoji nacija-država s kojom se može identificirati. U prvom promatranom razdoblju, na Olimpijskim igrama u Seoulu 1988. godine ta je identifikacija bila moguća, dok je u drugom razdoblju, unatoč osvojenoj medalji 1992. godine, sportski uspjeh zasjenjen političkom situacijom u zemlji, naročito sankcijama zbog kojih nastupa bez nacionalnih obilježja. Tu se jasno vidi miješanje elemenata građanskog i etničkog poimanja nacionalizma.

Zanimljiva je činjenica da su njezini sportski rezultati konstantni i uvijek na visokoj razini, no odnos javnosti prema ostvarenom rezultatu mijenja se ovisno o tome pod kojom zastavom postiže određeni rezultat. Dokaz je tome podatak da joj je nakon Olimpijskih igara u Seoulu 1988. godine, na kojima je nastupala pod jugoslavenskom zastavom i gdje je osvojila dvije medalje, priređen svečani doček najprije na beogradskom aerodromu, a nedugo zatim i u Osijeku, gradu u kojem je živjela. Četiri godine nakon, 1992. godine ponovno osvaja medalju pod olimpijskom zastavom, nakon čega joj u Beogradu nije priređen nikakav doček. Jasna Šekarić bila je sudionica sedam Olimpijskih igara od Seoula pa do danas, osvojila je pet olimpijskih medalja, no doček joj je priređen samo u prvom promatranom razdoblju, 1988. godine.

Činjenica da je Jasna Šekarić nastupala za četiri različite države (Socijalističku Federativnu Republiku Jugoslaviju, Saveznu Republiku Jugoslaviju, Državnu zajednicu Srbije i Crne Gore te Republiku Srbiju), a da pritom nije mijenjala državljanstvo dovode do zanimljivog pitanja - čije su medalje? Inače, taj je problem predmet mnogih rasprava koje se na području bivše Jugoslavije vode posljednjih četvrt stoljeća. Prvu olimpijsku medalju iz Seoula osvojila je nastupajući za SFRJ, u trenutku kad je živjela i trenirala u Hrvatskoj, o čemu će reći: „Ja sam osvojila tu medalju pod zastavom Jugoslavije $i$ to se tako vodi. Sad ajde da netko bude pametan da meni objasni kako da se to podeli, neka i meni to netko objasni. "(Jasna Šekarić, intervju, Zagreb, 6. 12. 2014.). Više će puta ponoviti: „Znate što... medalje su moje."(Srčnik, 2009.). Navedena izjava indikator je građanskog nacionalizma. Jasna Šekarić odbija bilo kakve podjele te svoje uspjehe gleda isključivo u sportskom kontekstu. Da je njena izjava glasila npr. „medalje su hrvatske/srpske“, tada bi to bio indikator etničkog nacionalizma.

Postoje i drugačija mišljenja. Na pitanje čija je osvojena medalja iz Seoula Mirela Skoko-Ćelić, bivša reprezentativka, olimpijka i kolegica Jasne Šekarić, odgovara:

Medalje su hrvatske $i$ osječke. Po meni, uzela ih je iz ove sredine. Je to onda bila Jugoslavija, ali to je manje bitno. Bitno je da se zna gdje je ona trenirala, s kim je bila na toj Olimpijadi, tko ju je pripremio, koja sredina je to investirala i uložila novce. To je bio grad Osijek, da bi se došlo do te medalje. (Mirela Skoko-Ćelić, intervju, Osijek, 2. 1. 2015.) 
Sličnog je mišljenja i tadašnji trener Jasne Šekarić, Zvonimir Kovačević, koji kaže:

Dakle u našem proračunu, to je medalja tu nas iz Osijeka, streljačkog društva Osijek a onda i Hrvatske. [...] razdvajaju se strijelci, pardon sportaši, na ono po porijeklu i po tome za koji je klub pucao odnosno trčao, skakao, plivao $i$ ne znam šta. To je dvojbeno u stvari. Po meni je ono sve što je ostvareno $u$ Hrvatskoj, bio netko Srbin, Makedonac ili Slovenac, to pripada Hrvatskoj po meni, i tom gradu, i tom klubu nekom gdje je netko bio, jel. [...] za mene to nije dvojbeno. Za mene onaj tko je nastupao u to vrijeme za neki klub iz Hrvatske, medalja je od Hrvatske. (Zvonimir Kovačević, intervju, Osijek, 2. 1. 2015.)

Interesantno je da tijekom intervjua trener Kovačević objašnjava sportske motive prelaska Jasne Šekarić u beogradski klub, što izrijekom razumije i opravdava, u čemu nalazimo indikatore građanskog oblika nacionalizma. Istovremeno, etničko poimanje nacionalizma nalazimo u objašnjenju prestanka međusobne komunikacije, jer da je Šekarić ostala u Osijeku: „nikom ništa, šta. Pa onda si tu, tu si i naš si. A sad si ti stanounik druge države koja ratuje sa mojom državom, o čem mi da pričamo."

Kako je već rečeno, sport i sportski uspjesi ovise o dominantnoj kulturi i vrijednostima određenog društva, te se mijenjaju paralelno s društvenim promjenama koje se zbivaju u pozadini, što možemo vidjeti i u konkretnom primjeru Jasne Šekarić. Njezini su sportski uspjesi konstantni. Ona je sportašica koja se nalazi u samom vrhu streljaštva tridesetak godina. Unatoč tome percepcija javnosti o njezinim uspjesima mijenja se sukladno tome kako se mijenjaju društvene okolnosti. Konkretno, 1988. godine njezini se uspjesi slave na najvišoj mogućoj razini: „I onda doček na aerodromu i posle toga kola koja je grad Osijek poslao specijalno za mene, limuzinu. Pa onda prolaza u kolima kroz korzo gde samo tramvaji idu i ja prolazim, decu su ranije iz škola pustili. "(Jasna Šekarić, intervju, Zagreb, 6. 12. 2014.).

Samo četiri godine nakon, u drugom proučavanom razdoblju, ponovno osvaja medalju na Olimpijskim igrama, ali ovaj put hrvatske novine gotovo da ne izvještavaju o njenim uspjesima. Tu medijsku šutnju, odnosno svojevrsno ignoriranje mogli bismo dijelom pripisati društvenom statusu streljaštva kao malog sporta, ali i interpretirati ga u kontekstu etničkog nacionalizma, nepriznavanja ili (namjernog) ignoriranja uspjeha „onih“, „drugih“, tj. „njih“. Dokaz tome pronalazimo u članku iz Sportskih novosti iz 1992. godine, u kojem je pisalo: „Od svih krugova više vrijedi pobjeda što su dobili toliko prostora u svjetskim medijima da pričaju o pravoj, srpskoj agresiji na svoju domovinu. Agresori, ovdje sakriveni pod nazivom nezavisna reprezentacija upucali su broncu. "(Zorko, 1992.:5).

Ako se njeno ime i spominje, to je obično u negativnom kontekstu, kao npr.: „Nekad ( $i$ nikad više) Osječanka, danas 'nezavisna olimpijka'. U kvalifikacijama je strabovito pucala, sa 389 krugova i olimpijskim rekordom upala je u finale. Pucala je od veselja, ali puca ona i od debljine. Mora imati sigurnu ruku kada ima nisko i široko 
težište. Nismo htjeli ići gledati to finale, mučnine je bilo dosta od vrućine. Kamoli od 'njihovih' slavlja." (Zorko, 1992.:6). U konkretnom primjeru vidljiva je promjena percepcije uspjeha sukladno društveno-političkim promjenama. Jasna Šekarić u trenutku ratnih zbivanja našla se na drugoj strani, i iz tog su razloga njezini sportski uspjesi omalovažavani. Osim što tu izjavu karakterizira odnos „mi“ i „oni“, tipičan za diskurs etničkog nacionalizma, ona je i rodno krajnje neprimjerena.

Jasna Šekarić sportašica je koja se ograđuje od političke scene i od pokušaja da se njenim sportskim rezultatima manipulira u političke svrhe. Smatra kako su sport i politika odvojene kategorije, koje se ne bi smjele miješati. Na pokušaje podjele njezinih sportskih uspjeha i sama odgovara:

Vi teritorij možda možete da podelite, možete da podelite nešto takvo, ali nešto kao medalje, nešto kao ja, mislim tko tu može da bude pametan i da napravi neku granicu. Mislim ja ne želim da uvredim Hrvatsku, ali isto tako ne želim da uvredim Srbiju, u kojoj ja danas živim i koja je moja zemlja. (Jasna Šekarić, intervju, Zagreb, 6. 12. 2014.)

Navedena izjava indikator je građanskog nacionalizma jer se u prvi plan stavljaju sportski uspjesi. Također je vidljivo kako nema podjele na „nas“ i „njih“. Iako joj je bitan isključivo sportski uspjeh te joj je manje bitna društveno-politička podloga, Šekarić je svjesna okoline, specifičnosti vremena i prostora te u skladu s tim i reakcija javnosti. Na pitanje bi li imala što protiv da je se uvrsti u hrvatsku sportsku dvoranu slavnih odgovara: „Ne bih imala ništa protiv. Druga je stvar bi li se time svi složili $i$ kako bi reagirali." (Lacković, 2009.:85).

U trećem razdoblju, kad nastupa za Državnu zajednicu Srbije i Crne Gore, nalazimo minimalan broj objava u srpskome tisku, iako se s Olimpijskih igara 2004. godine u Ateni vratila s osvojenim srebrom. Na percepciju uspjeha u tom slučaju utječe i činjenica da je streljaštvo tzv. mali sport. U novinskim člancima tijekom prvog proučavanog razdoblja nazivali su je: ,prvom damom jugoslavenskog (osječkog) sporta“, „her Olympic highness“, „ikonom sporta“, u ostalim razdobljima „najtrofejnijom srpskom sportašicom“, „najvećim srpskim sportašem“ i sl., no unatoč tome ona nema gotovo nikakav širi društveni utjecaj. U četvrtom razdoblju, od 2006. nadalje, nastupa za Republiku Srbiju. 2008. godine nastupala je na Olimpijskim igrama u Pekingu, gdje je predvodila sportaše svoje zemlje u defileu noseći zastavu. Nastupala je i na Olimpijskim igrama u Londonu 2012. godine. Na navedenim natjecanjima neće uspjeti osvojiti olimpijsko odličje. U člancima iz hrvatskih i srpskih medija prevladava sportski diskurs. Kada Streljački savez Srbije neposredno pred Olimpijske igre u Riju de Janeiru odlučuje prepustiti olimpijsku normu drugom strijelcu, veću pozornost Jasni Šekarić daju hrvatski mediji, koji koriste diskurs građanskog nacionalizma, nazivajući je sportskom ikonom i osobom koja je zadužila srpski sport. 


\section{Zaključak}

Kao što je već rečeno, svaka osoba posjeduje više različitih identiteta, no nacionalni identitet, u određenom vremenu i prostoru, ima moćniji i trajniji utjecaj od drugih kolektivnih kulturnih identiteta (Smith, 1991.). Isto tako, globalno gledano, sport je u sve većoj mjeri povezan s višedimenzionalnom matricom kulturnih, ekonomskih, ekoloških i političkih sfera u suvremenom društvu (Jackson i Haigh, 2008.:352). Rezultati brojnih istraživanja pokazuju da odnos sporta, nacionalnog identiteta i nacionalizma ovisi o kontekstu vremena i prostora. Tako i u ovom radu možemo zaključiti kako percepcija uspjeha Jasne Šekarić ovisi o društveno-političkoj situaciji i društvenim zbivanjima u konkretnom socijalnom kontekstu. To se prije svega odnosi na raspad SFRJ-a i stvaranje novih nacionalnih država. Uslijed dezintegracije Jugoslavije događaju se brojne promjene ne samo u društveno-političkom smislu nego i na području sporta i postizanja sportskih rezultata. Novonastala situacija direktno se odrazila na sportske uspjehe, što je vidljivo iz nekoliko činjenica. Kao prvo, država više ne stoji iza sporta na onaj način na koji se to događalo prije početka navedenih promjena. Kao drugo, sportaši su prisiljeni nastupati pod različitim zastavama, ovisno o vremenskom periodu u kojem nastupaju i za koju državu. Tako Jasnu Šekarić srpski dnevni list Politika zove „zastavnikom ispod pet zastava“. Uza sve navedeno percepcija uspjeha ovisi i o tome kako se percipira streljaštvo kao sport te kako se percipira Jasna Šekarić kao žena.

Izradi rada pristupili smo s hipotezom da društveno-politička situacija može značajno utjecati na percepciju sportskog uspjeha, što se u potpunosti potvrdilo. U prvom promatranom razdoblju sportski uspjesi Jasne Šekarić stavljaju se u prvi plan, te tada govorimo o dominaciji građanskog nacionalizma. Diskurs se približava etničkim nacionalizmu u drugom promatranom razdoblju, što svakako ima veze s ratnom situacijom i zbivanjima na široj društvenoj sceni. Njeni se sportski uspjesi nastoje obezvrijediti ili makar umanjiti. U trećem razdoblju hrvatski mediji ignoriraju njen uspjeh, no razlozi za to mogu ležati i u činjenici da je riječ o ženi ili o malom sportu. Četvrto razdoblje karakterizira diskurs građanskog nacionalizma.

Nakon obrade i analize svih podataka možemo donijeti dva zaključka. Prvi zaključak odnosi se na potvrdu postavljene glavne hipoteze. Iz svega navedenog u radu može se zaključiti da društveno-političke okolnosti zaista utječu na percepciju sportskog uspjeha, u našem slučaju uspjeha Jasne Šekarić. Drugi zaključak odnosi se na odnos građanskog i etničkog identiteta. Nakon analize svih podataka zaključili smo da podjela na građanski i etnički tip nacionalizma ne može biti striktno promatrana. Kada uzmemo u obzir tri analizirane dimenzije (političkog i medijskog diskursa te diskursa sportskih aktera), nije moguće prepoznati obilježja samo jednog tipa nacionalizma, stoga zaključujemo da u svim razdobljima zapravo dolazi do ispreplitanja obaju tipova nacionalizma te da svaki nacionalizam sadrži i građanske i etničke elemente. Također, ta se hipoteza zasniva jednim dijelom na sociološkim idealnim tipovima, pa je očekivano da se idealni tip ne može po definiciji poklapati u potpunosti $s$ društvenom stvarnošću, a naša stvarnost posljednja tri desetljeća, kako slučaj Jasne Šekarić dobro pokazuje, obilježena je ispreplitanjem i privremenom dominacijom nekog od smjerova i oblika (bilo građanskog bilo etničkog) nacionalizma. 
Jasna Šekarić u svojoj dugoj sportskoj karijeri nastupala je na sedam Olimpijskih igara osvojivši pritom pet olimpijskih medalja. Njen sportski rezultat možda će nekada biti nadmašen, no po nečemu slučaj Jasne Šekarić ostat će jedinstven. Nastupanje na Olimpijskim igrama pod pet različitih zastava, za četiri različite države, u dresovima pet različitih država-nacija rezultat je posebnih društveno-političkih i ratnih zbivanja, koja teško da će se u tom obliku ponoviti.

\section{Literatura}

1. Bartoluci, S. (2013). Uloga vrhunskog sporta u oblikovanju nacionalnog identiteta u Republici Hrvatskoj: usporedba devedesetih i dvijetisućitih: doktorska disertacija. Filozofski fakultet Sveučilišta u Zagrebu.

2. Gratton, C. and Jones, I. (2010). Research Methods for Sport Studies. London and New York: Routledge. $2^{\text {nd }}$ edition.

3. Hancock, D. R. and Algozzine, B. (2006). Doing case study research. A practical guide for beginning research. New York: Teachers College Press.

4. Harrison, G. (1988). L'eco clamorosa, u: Salvini, A. (Ur.). Il rito agressivo. Firenze: Giunti, 235-273.

5. Jackson, S. J. and Haigs, S. (2008). Between and beyond politics: Sport and foreign policy in globalizing world. Sport in Society, 11 (4): 349-358.

6. Jutel, A. (2002). Olimpic road cycling and national identity: where is Germany? Journal of Sport \& Social Issues, 26 (2): 195-208.

7. Lacković, K. (2009). Uz Osijek me vežu dragi ljudi i doček nakon Seoula. Glas Slavonije, rujan 2009.

8. Lakić, I. (2009). Modeli analize diskursa novinskih članaka. Riječ, 2: 91-108.

9. Lakoff, S. (2000). Nacija i demokracija. Politička misao, 37 (1): 56-83.

10. McCrone, D. (1998). The Sociology of Nationalism. London and New York: Routledge.

11. Perasović, B. i Bartoluci, S. (2007). Sociologija sporta u hrvatskom kontekstu. Sociologija i prostor, 175 (1): 105-119.

12. Ravlić, S. i Sekulić, D. (2008). Nacija i nacionalizam, u: Kregar, J.; Sekulić, D.; Ravlić, S.; Grubišić, K. (Ur.). Uvod u sociologiju. Zagreb: Pravni fakultet Sveučilišta u Zagrebu, 451-478.

13. Srčnik, A. (2009). Šekarić: Medalje su moje, ni srpske ni hrvatske. (http:// www.jutarnji.hr/sport/sport-mix/sekaric-medalje-su-moje-ni-srpske-ni-hrvatske/2825561/). Jutarnji.hr, srpanj 2009.

14. Smith, A. D. (1991). National Identity. London: Penguin Books.

15. Vrcan, S. (1990). Sport i nasilje danas u nasi druge studije iz sociologije sporta. Zagreb: Naprijed.

16. Zorko, M. (1992). Već sam gledala medalju. Sportske novosti, kolovoz 1992. 
Sunčica Bartoluci

University of Zagreb, Faculty of Kinesiology, Croatia

e-mail: suncica.bartoluci@kif.hr

Lorena Draženović

University of Zagreb, Faculty of Kinesiology, Croatia

e-mail: lorena.drazenovic@kif.hr

Five Flags, Four Countries, One Citizenship - and whose are the Medals?*

\begin{abstract}
Pistol shooter Jasna Šekarić is an athlete who has, in her exceptionally long sports career, competed under five different flags and for four different countries without ever changing her citizenship. The goal of this scientific research was to analyse the influence of sociopolitical circumstances on the perception of her sport success and the shaping of national identity during four periods (four countries for which Jasna Šekarić performed). We used Anthony D. Smith's dichotomy of civic and ethnic nationalism as a theoretical framework. We assumed that socio-political circumstances could significantly influence the perception of a specific sport success, given the fact that the four observed periods witnessed huge social turbulence and ethnic and civic nationalism. In order to collect the necessary data to confirm the research hypothesis, the case study qualitative method was implemented. For the analysis of the case study, various methods were used - three semi-structured interviews with sports people involved and a discourse analysis (newspaper, magazine and online articles, different documents). The case study analysis confirmed the expected results. It was shown that socio-political circumstances indeed affected the perception of Jasna Šekarićs sport success. Also, the results showed that in the four studied periods it was not possible to unambiguously identify characteristics of ethnic or civic nationalism.
\end{abstract}

Key words: sport success, national identity, sports, ethnic nationalism, civic nationalism.

* The text partly originates from the paper Five flags, five medals, eight Olympic Games: Jasna Šekarić - a case study, by Lorena Draženović, mentor Sunčica Bartoluci. The paper received the Rector's award for a scientific paper in the academic year 2014/2015. 